\title{
Trophic partitioning among three littoral microcrustaceans: relative importance of periphyton as food resource
}

\author{
Hélène MASCLAUX,,$^{1,2 *}$ Alexandre BEC, ${ }^{1,2}$ Gilles BOURDIER ${ }^{1,2}$ \\ ${ }^{1}$ Clermont Université, Université Blaise Pascal, LMGE, BP 10448, 63000 Clermont-Ferrand, France; ${ }^{2}$ CNRS, UMR 6023, LMGE, \\ 63173, Aubière, France. \\ *Corresponding author: helene.masclaux@univ-bpclermont.fr
}

\begin{abstract}
The high species richness of zooplankton communities in macrophytes littoral zones could result from the diversity of potential trophic niches found in such environment. In macrophytes littoral zones, in addition to phytoplankton, neustonic, benthic and epiphytic biofilms can also be potential components of the microcrustacean diet. Here, we investigated the ability of three large cladocerans: Daphnia longispina, Simocephalus vetulus and Eurycercus lamellatus, to develop on periphyton as their only food source or as a complement to a phytoplankton resource in scarce supply. D. longispina exhibited a very low growth and reproduction rates on the periphytic resource and as S. vetulus seems to be able to feed mainly on suspended particles. In contrast, E. lamellatus could not grow on phytoplankton, and appears to be an obligatory periphyton scraper. This latter finding contrasts with previous studies suggesting that E. lamellatus could be able to scrape periphyton as well as filter-feed on suspended matter. These differences in feeding strategy probably reflect the different trophic niches occupied by these three species in macrophytes littoral zones, and may explain at least in part their ability to coexist in the same environment.
\end{abstract}

Key words: feeding behavior, food resources, trophic niches, periphyton.

Received: January 2012. Accepted: April 2012.

\section{INTRODUCTION}

Trophic partitioning is a key element underlying the stable coexistence of competitors and the maintenance of species diversity in a given environment (Chesson, 2000; Levine and HilleRisLambers, 2009). Macrophytes littoral zones sustain a wide range of different life forms, ranging from those attached to surfaces to those that swim or float freely in the water column. Littoral or semilittoral species are major contributors to microcrustacean diversity, with about $75 \%$ of the zooplankton species inventoried in lakes being classified as littoral species (Walseng et al., 2006). In littoral zones, aquatic macrophytes play an important role in increasing the habitat complexity of the waterscape, thus providing more potential ecological niches. Indeed, zooplankton trophic niches are much more diversified in macrophytes littoral zones than in the pelagic environment, and, in addition to planktonic particles, they also contain neustonic, benthic, and epiphytic biofilms, which may be potential components of the microcrustacean diet.

Periphyton can make up a considerable proportion of the total primary production of lakes, especially in shallow lakes, where it can be responsible for $80-98 \%$ of primary production (Cattaneo et al., 1997; Vadeboncoeur et al., 2003). However, little is known about the role of periphytic production in the food web dynamics of such an environment (Cattaneo et al., 2004; Siehoff et al., 2009; Booker and Cheruvelil, 2011). Hitherto, the only cladocerans known to exploit periphytic biofilms were Chydorideae species (van de Bund et al., 1994). However, in recent studies Siehoff et al. (2009) and Cazzanelli et al. (2012) showed that Daphnia magna and Daphnia middendorffiana are also able to feed on periphytic and benthic resources, especially when phytoplankton is scarce.

In this study, we conducted laboratory experiments involving three species of cladocerans found in littoral habitats, Daphnia longispina, Simocephalus vetulus (Daphnideae) and Eurycercus lamellatus (Chydorideae), which were fed with three food sources: periphyton, phytoplankton, and a mixture of periphyton and phytoplankton. The aim of this study was to investigate how common periphyton scraping is as mode of feeding among cladocerans in littoral zones. Indeed, if there is a growing appreciation that periphytic production may also be an important resource for invertebrate consumers, little is known about the species really able to feed on it. A broader understanding of how the different food sources are used by littoral microcrustaceans could thus help to elucidate how such large numbers of zooplankton species can co-exist in the same environment. It can also give important information regarding the dynamic of cladoceran community. 


\section{METHODS}

\section{Origin of the planktonic food source}

Scenedesmus obliquus SAG 276-3a was grown in Cyano medium (von Elert and Wolffrom, 2001) at $18^{\circ} \mathrm{C}$, and cultured semicontinuously at a dilution rate of 0.25 $\mathrm{d}^{-1}$ in aerated 3-L vessels. The stock solution of Scenedesmus for the growth experiments was prepared by centrifuging and resuspending the cultured cells in Cyano medium. The carbon concentration of the autotrophic food suspension was estimated from the photometric light extinction $(800 \mathrm{~nm})$, and from the previously-determined carbon-extinction regression (D. Martin-Creuzburg, personal communication).

\section{Origin of the periphytic food source}

Four months before the experiments (from February to May), glass rods (about $16 \mathrm{~cm}^{2}$ ) were immersed in a backwater of the Allier river $\left(3^{\circ} 28^{\prime} \mathrm{E}, 46^{\circ} 01^{\prime} \mathrm{N}\right)$ to allow attached algae and other microorganisms to colonize them. Before they were placed in the experimental beakers, they were lightly rinsed in filtered river water in order to remove any particles likely to come off the rod and become planktonic. Moreover, as periphyton can be patchy in its distribution (Biggs, 1996), glass rods having a homogeneous distribution of periphyton and a similar appearance were chosen. We thus expected that quantity and quality of periphyton were the same in all beakers.

\section{Origin and maintenance of zooplankton species}

Daphnia longispina, Simocephalus vetulus and Eurycercus lamellatus, three large microcrustaceans found in littoral habitats, were used for this experiment. All three species were collected from a backwater sampling site of the Allier river, where they dominate cladoceran community. Females were then maintained during two weeks in $1 \mathrm{~L}$ containers containing $50 \%$ of filtered river water $(<0.2$ $\mu \mathrm{m})$ and $50 \%$ of ADaM medium (Klüttgen et al., 1994), with a maximum of 20 individuals per liter and with a 12:12 h light:dark cycle, at $18^{\circ} \mathrm{C}$. They were fed once a day with Scenedesmus ad libitum $\left(2 \mathrm{mg} \mathrm{CL}^{-1}\right.$, i.e. well above the incipient limiting level that is reported to be approximately $0.5 \mathrm{mg} \mathrm{C} \mathrm{L}^{-1}$; (Lampert, 1978). In addition to Scenedesmus, two rods on which periphyton had grown were added to the E. lamellatus containers.

\section{Experimental set-up}

In this experiment, we used to measure the somatic growth rate of the different cladoceran species fed on the different food sources as it has been shown to be a good measure of cladoceran fitness (Lampert and Trubetskova, 1996).

One clone of each cladoceran species was isolated. The clones were then transferred to $1 \mathrm{~L}$ containers containing $50 \%$ filtered river water $(<0.2 \mu \mathrm{m})$ and $50 \%$ ADaM medium, and fed with Scenedesmus ad libitum every day. Rods on which periphyton had grown were added to the E. lamellatus containers. When the females produced offspring, the neonates (first brood of the first generation) were separated, and the mothers removed. This step was repeated, and the second generation kept. After they had released their first clutch, females from the second generation were kept and the neonates removed. The individuals used in the experiments were third-brood offspring obtained from the second generation in order to limit variability due to maternal size and weight (Lampert, 1993). Neonates were collected about $12 \mathrm{~h}$ after they had been released, and randomly placed in 200-mL beakers (10 individuals per beaker). Experiments were performed on four food sources with three replicates of each treatment. The four food sources used were: Scenedesmus at a nonlimiting concentration $\left(2 \mathrm{mg} \mathrm{C} \mathrm{L}^{-1}\right)\left(\mathrm{S}^{+}\right)$, Scenedesmus at a limiting concentration (0.3 $\left.\mathrm{mg} \mathrm{C} \mathrm{L}^{-1}\right)\left(\mathrm{S}^{-}\right)$, Scenedesmus at a limiting concentration $\left(0.3 \mathrm{mg} \mathrm{C} \mathrm{L}^{-1}\right)$ plus periphyton (one rod) $(\mathrm{S}+\mathrm{P})$, and periphyton alone (two rods) (P). During the experiments, individuals were transferred into clean water and fed every day. The periphyton rods used in the different treatments were changed every day.

To determine the average initial dry weight $\left(\mathrm{W}_{0}\right)$, randomly selected neonates from the brood that yielded the neonates used in the experiments, were transferred into tared aluminum containers (two samples of 30 neonates for both $D$. longispina and $S$. vetulus, and two samples of 20 neonates for $E$. lamellatus), dried overnight at $60^{\circ} \mathrm{C}$, cooled in a desiccator, and weighed on an electronic balance (Mettler Toledo UMX2 balance $\pm 1 \mu \mathrm{g}$ ). The experiments were stopped when the females reached maturity, which took between 4 and 7 days for D. longispina, between 6 and 9 days for S. vetulus, and between 6 and 7 days for E. lamellatus, on the treatment containing periphyton. When E. lamellatus was fed on Scenedesmus as its only food sources, all the individuals died before reaching maturity. Individuals were collected, the clutch size was measured (eggs per individual), and females were dried overnight at $60^{\circ} \mathrm{C}$ and then weighed to obtain the average individual weight per replicate $\left(\mathrm{W}_{\mathrm{t}}\right)$. Somatic growth rates $(\mathrm{g})$ were calculated as

$$
g=\left(\ln W_{t}-\ln W_{0}\right) / t
$$

where $t$ is the duration of each experiment in days.

\section{Data analysis}

The effects of food source on somatic growth rate and clutch size of $D$. longispina, $S$. vetulus, and E. lamellatus were analyzed by a one-way ANOVA $(\alpha<0.05)$. Pairwise comparisons were made with a post-hoc test [Tukey's 
Honestly Significant Difference (HSD)] with Bonferroni adjustment $(\alpha<0.008)$.

\section{RESULTS}

\section{Effects of food sources on D. longispina, S. vetulus, and E. lamellatus clutch size}

For $D$. longispina and $S$. vetulus, the clutches of females fed on Scenedesmus at a non-limiting concentration $\left(\mathrm{S}^{+}\right)$ were significantly larger than those of females fed on periphyton alone (P) (Fig. 1, Tab. 1). In spite of their intermediate values, the clutch sizes obtained for the treatments with Scenedesmus at a limiting concentration with or without periphyton (S+P and $\mathrm{S}^{-}$respectively) were not significantly different from those for the other two treatments.

For E. lamellatus, maturity was reached only with the two treatments containing periphyton (Fig. 1). The clutch sizes for these two treatments were not significantly different (Tab. 1).

\section{Effects of food sources on the growth rates of D. longispina, S. vetulus, and E. lamellatus}

For D. longispina, the highest growth rates were recorded when the females were fed on $\mathrm{S}^{+}$, and the lowest ones when the females were fed on P (Fig. 1, Tab. 1). Intermediate growth rates were recorded for the females fed on $\mathrm{S}^{-}$and on $\mathrm{S}+\mathrm{P}$.

As for $D$. longispina, the lowest growth rates of $S$. vetulus were recorded when individuals were fed on P (Fig. 1, Tab. 1), but for this species, the $\mathrm{S}+\mathrm{P}$ mixture produced the highest growth rates. The intermediate values obtained with the two concentrations of Scenedesmus did not differ significantly.

All the E. lamellatus individuals fed on Scenedesmus as their only food source died after 8 days on $\mathrm{S}^{+}$, and after 14 days on $\mathrm{S}^{-}$(Fig. 1). The individuals reached maturity on both the treatments containing periphyton, and growth rates on these treatments were the same (Tab. 1).

\section{DISCUSSION}

In this study, we aimed at assessing how common periphyton scraping is as mode of feeding among three large cladocerans of littoral zones. Indeed, we expected that differences in food resources use could be a factor of maintenance of species diversity and a factor explaining the dynamics of cladoceran communities in natural environment. Moreover, as periphytic production could be responsible for the main proportion of primary production in shallow environment (Vadeboncoeur et al., 2003), we feel that a better understanding of how periphytic resources is used by the main large microcrustaceans could help to assess energy transfer pathways in freshwater aquatic food webs. However, if differences in feeding habits have already been suggest in field study (Balayla and Moss, 2003), there is still few experimental investigations on the subject. This experiment was performed as clutch size and somatic growth rate has been shown to be a good indicator of cladoceran fitness (Lampert and Trubetskova, 1996).

Two recent studies showed that some species of the genus Daphnia are able to graze on periphyton (Siehoff $e t$ al., 2009; Cazzanelli et al., 2012). According to Siehoff et al. (2009), periphyton could be an alternative food source for the population of D. magna, especially when phytoplanktonic resources become scarce. In this study, we found that the highest growth rates of the daphniid S. vetulus were obtained on the Scenedesmus + periphyton mixture. However, this pattern was not observed for the fecundity data. Even if a previous field study suggested that a large proportion of the diet of this species could be from periphytic material (Balayla and Moss, 2004), our results do not allow us to corroborate this hypothesis but rather suggest that $S$. vetulus fed mainly on planktonic particles. In the same way, D. longispina exhibited low somatic growth rates and clutch sizes when fed on periphyton. However, the addition of periphyton did not increase growth rates of $D$. longispina fed on limiting concentrations of Scenedesmus. In this study, we cannot totally exclude that some particles were detached from the support to become planktonic and therefore available for individuals. However, the rods were rinsed before the experiment to minimize this bias. Siehoff et al. (2009) also found an increase in D. magna population abundance during the first week of population experiments even when they were starved. Controlled experiments have moreover shown that mothers provision their offspring with energy and biochemical compounds (Goulden et al., 1987). Hence, in our study, the slight development of $D$. longispina on periphyton treatments could be due to maternal effects. However, if it seems that $D$. longispina, as $S$. vetulus, is mainly able to forage on planktonic particles, our results tend to show that this species could be also able to feed on periphyton. Further studies performing longer population experiments have to be done to specify the feeding behavior of these two species concerning periphytic resources.

Finally, E. lamellatus exhibited high somatic growth rates and was able to produce eggs when individuals were fed on periphyton. It is interesting to note that even if there was twice the amount of periphyton in the $\mathrm{P}$ treatment compared to the $\mathrm{S}+\mathrm{P}$ treatment, the somatic growth rate were the same in both of them, suggesting that the amount of periphyton was not limiting in this study. We found surprisingly that E. lamellatus cannot develop on the phytoplanktonic species Scenedesmus. Smirnov (1962) also found that this species died within a few days when fed on Chlorella terricola, another phytoplanktonic species. However, Chydorid cladocerans are usually con- 
sidered to be able to exploit both periphyton and phytoplankton food sources (Meyers, 1984). Besides, Fryer (1963) and Beklioglu and Jeppesen (1999) suggest that $E$. lamellatus could be able to scrape periphyton as well as filter-feed on suspended matter. The experiments per- formed by these last authors aimed to assess habitat preference and behavioral responses of E. lamellatus at different food sources and exposed to fish cues, through short observations of $10 \mathrm{~min}$. This protocol allowed them to highlight that this species prefer plant dwelling to avoid
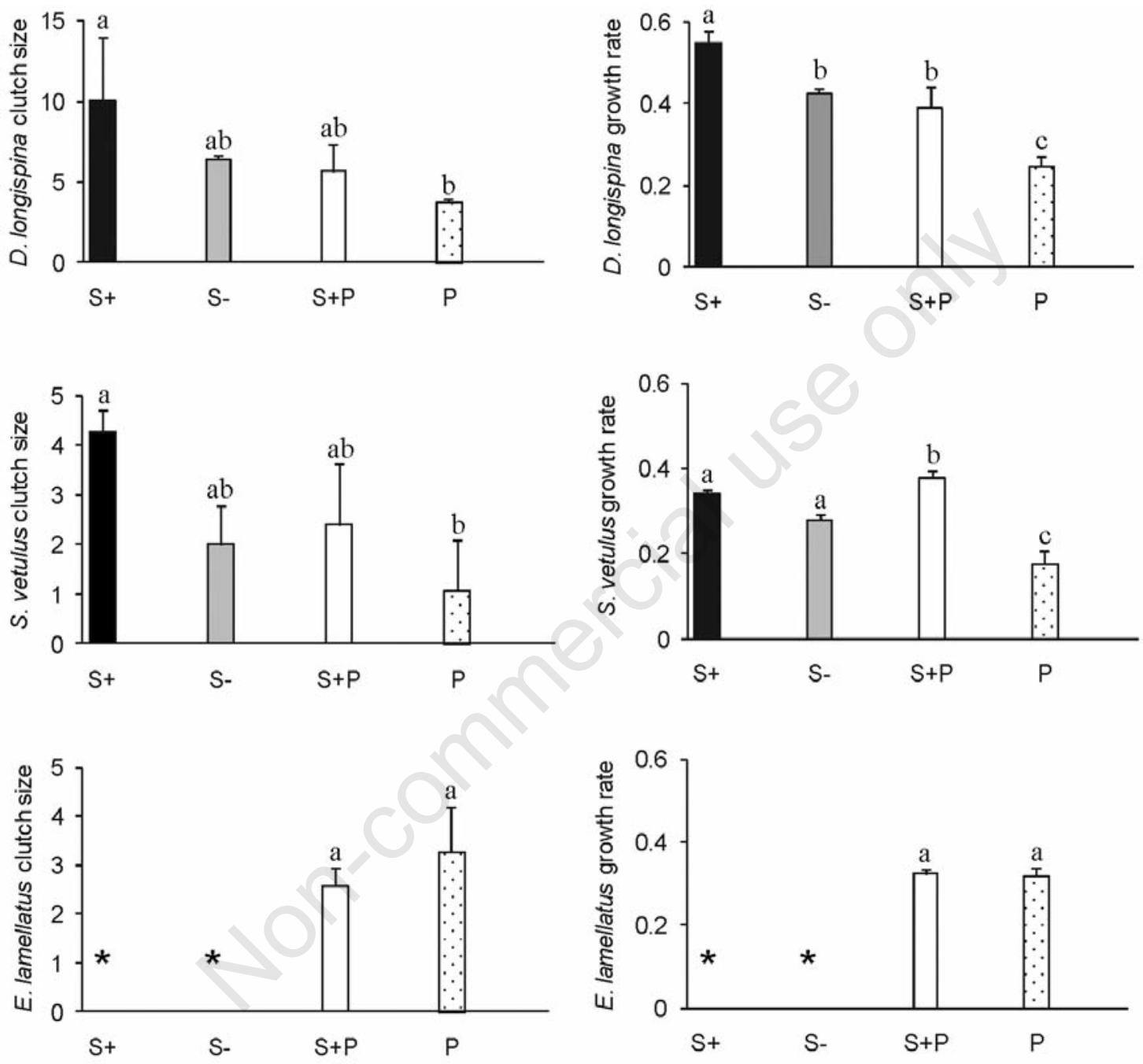

Fig. 1. Effects of food resource on clutch size (left) and growth rate (right) of Daphnia longispina, Simocephalus vetulus and Eurycercus lamellatus. Data are means + SD on three replicates per treatments. On treatments labeled with * all the individuals died after a few days. Bars labeled with the same letters are not significantly different (Tukey's HSD, $\mathrm{P}<0.008$ ). The results of the different treatments are represented by different colors: black for Scenedesmus at a nonlimiting concentration $\left(\mathrm{S}^{+}\right)$, grey for Scenedesmus at a limiting concentration $\left(\mathrm{S}^{-}\right)$, white for Scenedesmus at a limiting concentration plus periphyton $(\mathrm{S}+\mathrm{P})$, and dotted columns for periphyton alone $(\mathrm{P})$.

Tab. 1. Results of the one-way ANOVA test on the effect of food sources on D. longispina, S. vetulus and E. lamellatus clutch size and growth rate in the first experiment.

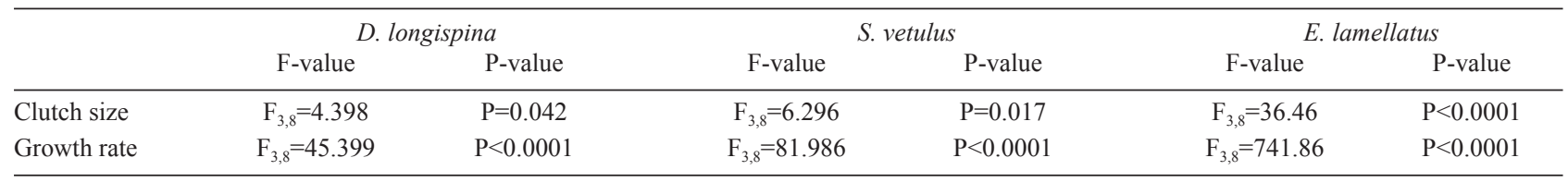


predation and because of the presence of epiphyton. However, their protocol was not performed to test the ability of E. lamellatus to feed on planktonic particle. To our knowledge, our study is the first to test through controlled laboratory experiments, the current consensus claiming that Eurycercus can use both resources, periphyton and suspended material. Our results strongly suggest that contrary to previous assumptions, E. lamellatus is an obligatory scraper unable to feed on sestonic particles.

In shallow lakes, periphytic production can be responsible for the main proportion of primary production (Vadeboncoeur et al., 2003). E. lamellatus, with its feeding strategy that allows it to feed on a resource not available to other microcrustaceans, is probably very competitive in such an environment. Lemke and Benke (2004) reported a higher density of Eurycercus vernalis in the Nympheae zone in mid to late spring. Phytoplanktonic species are often not well developed at this time of year (Sommer et al., 1986), but Eurycercus probably found in the Nympheae zone a periphytic resource allowing the establishment of a dense population.

In a general way, the periphyton dynamics should also have a role on the success of Eurycercus. At that time of year when the water is still cold, Eurycercus probably benefits from feeding on polyunsaturated fatty acid (PUFA)-rich algae. Indeed, periphyton composition is season dependent and is dominated by PUFA-rich diatoms (Ahlgren et al., 1990) in winter and spring (Leland et al., 1986; Vymazal and Richardson, 1995). This means that the access to periphytic resource could not only confer a benefit in terms of food availability, but also provides periphyton scrapers with high quality food. It has been shown that food quality constraints on zooplankton development increase as temperature decreases, in part because of the high dietary requirements of zooplankton for PUFA at low temperatures (Masclaux et al., 2009). Thus, scraping a high quality periphyton food source may be of particular importance for microcrustacean development under such conditions.

\section{CONCLUSIONS}

Our study shows that the cladocerans found in littoral zones have differing abilities to forage on planktonic and periphytic components. S. vetulus and D. longispina appear to be able to feed mainly on suspended particles whereas E. lamellatus, contrary to what we thought until now, seems only able to graze on periphyton. Even if feeding niche segregation has to be verified through longer population experiments and in natural environment, we assume that feeding behavior could be a major factor determining the seasonal dynamics of cladoceran species in macrophyte-rich habitats.

It also appears that further studies are required to evaluate variations in periphyton food quality, especially with re- gard to its lipid content, as polyunsaturated fatty acids are considered as essential compounds for higher trophic levels.

\section{ACKNOWLEDGMENTS}

This research was supported by the French Ministry of the Education and Research and the Rivière Allier PPF Research Program.

The authors would like to thank Monika Ghosh for the corrections of English grammar and syntax.

\section{REFERENCES}

Ahlgren G, Lundstedt L, Brett MT, Forsberg C, 1990. Lipid composition and food quality of some freshwater phytoplankton for cladoceran zooplankters. J. Plankton Res. 12:809-818.

Balayla DJ, Moss B, 2003. Spatial patterns and population dynamics of plant-associated microcrustacea (Cladocera) in an English shallow lake (Little Mere, Cheshire). Aquat. Ecol. 37:417-435.

Balayla DJ, Moss B, 2004. Relative importance of grazing on algae by plant-associated and open-water microcrustacea (Cladocera). Arch. Hydrobiol. 161:199-224.

Beklioglu M, Jeppesen E, 1999. Behavioural response of plantassociated Eurycercus lamellatus (Ö.F. Müller) to different food sources and fish cues. Aquat. Ecol. 33:167-173.

Biggs BJF, 1996. Patterns in benthic algae of streams, p. 31-56. In: R.J. Stevenson, M.L. Bothwell and R.L. Lowe (eds.), Algal ecology: freshwater benthic ecosystems. Academic Press.

Booker DJ, Cheruvelil KS, 2011. Are zooplankton food resources poor in the vegetated littoral zone of shallow lakes? Freshw. Biol. 56:2459-2472.

Cattaneo A, Cloutier L, Méthot G, 2004. The response of invertebrates in moss and in gravel to water level fluctuations in a Québec stream. Arch. Hydrobiol. 161:21-43.

Cattaneo A, Kerimian T, Roberge M, Marty J, 1997. Periphyton distribution and abundance on substrata of different size along a gradient of stream trophy. Hydrobiol. 354:101-110.

Cazzanelli M, Forsstrom L, Rautio M, Michelsen A, Christoffersen KS, 2012. Benthic resources are the key to Daphnia middendorffiana survival in a high arctic pond. Freshw. Biol. 57:541-551.

Chesson P, 2000. Mechanisms of maintenance of species diversity. Annu. Rev. Ecol. Syst. 31:343-358.

Fryer G, 1963. The functional morphology feeding mechanism of chydorid cladocerans Eurycercus lamellatus (O.F. Müller). Trans. R. Soc. Edin. 65:335-381.

Goulden CE, Henry L, Berrigan D, 1987. Egg size, postembryonic yolk, and survival ability. Oecologia 72:28-31.

Klüttgen B, Dulmer U, Engels M, Ratte HT, 1994. Adam, an artificial fresh-water for the culture of zooplankton. Water Res. 28:743-746.

Lampert W, 1978. Field-study on dependence of fecundity of Daphnia spec. on food concentration. Oecologia 36:363369.

Lampert W, 1993. Phenotypic plasticity of the size at $1^{\text {st }}$ reproduction in Daphnia. The importance of maternal size. Ecology $74: 1455-1466$. 
Lampert W, Trubetskova I, 1996. Juvenile growth rate as a measure of fitness in Daphnia. Funct. Ecol. 10:631-635.

Leland HV, Steven VF, James LC, Mahood AD, 1986. Composition and abundance of periphyton and aqautic insects in a sierra navada stream. Great Basin Nat. 46:595-611.

Lemke AM, Benke AC, 2004. Growth, reproduction, and production dynamics of a littoral microcrustacean, Eurycercus vernalis (Chydoridae), from a southeastern wetland, USA. J. N. Am. Benthol. Soc. 23:806-823.

Levine JM, HilleRisLambers J, 2009. The importance of niches for the maintenance of species diversity. Nature 461:254258.

Masclaux H, Bec A, Kainz MJ, Desvilettes C, Jouve L, Bourdier G, 2009. Combined effects of food quality and temperature on somatic growth and reproduction of two freshwater cladocerans. Limnol. Oceanogr. 54:1323-1332.

Meyers DG, 1984. Habitat shifting, feeding mode versatility, and alternate resource by herbivorous cladoceran zooplankton in a montane lake. AAAS Nat. Annual Meet., 3-8 January 1981, Toronto, ON, Canada.

Walseng B, Hessen DO, Halvorsen G, Schartau AK, 2006. Major contribution from littoral crustaceans to zooplankton species richness in lakes. Limnol. Oceanogr. 51:2600-2606.

Vadeboncoeur Y, Jeppesen E, Vander Zanden MJ, Schierup HH,
Christoffersen K, Lodge DM, 2003. From Greenland to green lakes: cultural eutrophication and the loss of benthic pathways in lakes. Limnol. Oceanogr. 48:1408-1418.

Siehoff S, Hammers-Wirtz M, Strauss T, Ratte HT, 2009. Periphyton as alternative food source for the filter-feeding cladoceran Daphnia magna. Freshw. Biol. 54:15-23.

Smirnov NN, 1962. Eurycercus lamellatus (O. F. Müller) (Chydoridae, Cladocera): field observations and nutrition. Hydrobiologia 20: 280-294.

Sommer U, Gliwicz ZM, Lampert W, Duncan A, 1986. The pegmodel of seasonal succession of planktonic events in fresh waters. Arch. Hydrobiol. 106:433-471.

van de Bund WJ, Krips OE, Davids C, 1994. Potential food sources for littoral meiobenthos: culture experiments with Chydorus piger, p. 69-78. In: W.J. van de Bund (ed.), Food web relations of littoral macro- and meiobenthos. Dissertations, University of Amsterdam.

von Elert E, Wolffrom T, 2001. Supplementation of cyanobacterial food with polyunsaturated fatty acids does not improve growth of Daphnia. Limnol. Oceanogr. 46:1552-1558.

Vymazal J, Richardson CJ, 1995. Species composition, biomass, and nutrient content of periphyton in the florida everglades. J. Phycol. 31:343-354. 